\title{
Report of the Annual Meeting
}

Rapports annuels de la Société historique du Canada

\section{National Historic Parks and Sites, 1958-59}

\section{National Historic Sites Division, National Parks Branch et Department of Northern Affairs and National Resources}

Volume 38, numéro 1, 1959

URI : https://id.erudit.org/iderudit/300415ar

DOI : https://doi.org/10.7202/300415ar

Aller au sommaire du numéro

Éditeur(s)

The Canadian Historical Association/La Société historique du Canada

ISSN

0317-0594 (imprimé)

1712-9095 (numérique)

Découvrir la revue

Citer ce document

National Historic Sites Division, National Parks Branch \& Department of Northern Affairs and National Resources (1959). National Historic Parks and

Sites, 1958-59. Report of the Annual Meeting / Rapports annuels de la Société

historique du Canada, 38(1), 63-70. https://doi.org/10.7202/300415ar

All rights reserved @ The Canadian Historical Association/La Société historique du Canada, 1959
Ce document est protégé par la loi sur le droit d'auteur. L’utilisation des services d'Érudit (y compris la reproduction) est assujettie à sa politique d'utilisation que vous pouvez consulter en ligne.

https://apropos.erudit.org/fr/usagers/politique-dutilisation/ 


\section{NATIONAL HISTORIC PARKS AND SITES, 1958-59 BY THE NATIONAL HISTORIC SITES DIVISION, NATIONAL PARKS BRANCH, DEPARTMENT OF NORTHERN AFFAIRS AND NATIONAL RESOURCES}

The National Historic Parks and Sites Division is responsible for the operation and maintenance of 20 National Historic Parks and for the care and preservation of 574. Historic Sites which have been erected since 1922, an average of $1 \frac{1}{3}$ monuments per month for 36 years. The Historic Sites and Monuments Board of Canada, comprised of authoritative historians from each province, advises the Minister on the marking of historic sites, the commemorating of persons and places, including buildings of national historic interest by reason of their age or architectural design.

During the year, the old Commissariat Building, 17 St. Louis Street, Quebec City, was acquired. Restoration of the house was begun early in 1959 and it is hoped work will be completed in the summer of 1959. Work at Cartier-Brébeuf Park, Quebec City, commissioned by the Historic Sites Division, was carried out by the National Battlefields Commission. Land was acquired at the Alexander Graham Bell Museum, Batoche, Fort Malden, Grand Pré and Signal Hill National Historic Parks. Negotiations for additional areas of land were continued at Fort Malden.

The program of erecting monuments to mark historic places, events and prominent figures in Canadian history was continued with the establishment of tablets at Kamouraska, Quebec; Parliament Buildings, Toronto; Windsor, Ontario; Gravelbourg, Saskatchewan; Victoria B.C.; University of Saskatchewan and Newcastle, N.B.

We would also wish to draw attention to the increasing genuine interest in the work of the Historic Parks and Sites Division. This year we have answered numerous inquiries on divers topics of Canadian history. Persons of all ages, not only throughout Canada but also in the United States, have expressed a desire to have an intelligent knowledge of the history of Canada.

The Historic Parks and Sites Division is pleased to announce that Mr. Jack Douglas Herbert has been appointed as the new Chief of the Division. Mr. Herbert was recently with the Glenbow Foundation in Calgary. Born in Saskatoon in 1920, he later studied History (Honours) and Political Science at the University of Saskatchewan, and obtained his Master's Degree in History and Political Science at the University of Toronto. 
The Historic Sites and Monuments Board of Canada held two General Meetings in Ottawa this year, one in November and one in May. The present members of the Board are as follows: Rt. Rev. Mgr. A. d'Eschambault, Genthon, Manitoba, (Chairman); Dr. Walter N. Sage, Vancouver, British Columbia; Dr. W. Kaye Lamb, Dominion Archivist, Ottawa, Ontario; Dr. A. G. Bailey, Dean of Arts, Fredericton, New Brunswick; Dr. C. B. Fergusson, Halifax, Nova Scotia; Richmond Mayson, Esq., Prince Albert, Saskatchewan; Edouard Fiset, Esq., Quebec, P.Q.; Jules Bazin, Esq., Montreal, P.Q.; O. L. Vardy, Esq., St. John's, Newfoundland; Dr. A. R. M. Lower, Queen's University, Kingston, Ontario; Dr. D. G. Creighton, University of Toronto, Toronto, Ontario; Richard Y. Secord, Edmonton, Alberta, (recently appointed) ; J. D. Herbert, Chief, National Historic Parks and Sites Division, Ottawa, Ontario. (Secretary to the Board)

\section{NATIONAL HISTORIC SITES:}

\section{TABLETS UNVEILED IN 1958-59}

Honourable Jean Charles Chapais and his son Thomas, at St. Louis de Kamouraska, P.Q.

Meetings of the Parliament of Canada in Toronto prior to Confederation, Toronto, Ontario.

The François Baby House, Windsor, Ontario.

Father Louis-Pierre Gravel, Gravelbourg, Saskatchewan.

The Mooring Rings, Victoria, British Columbia.

Fort McLeod's Lake, British Columbia.

Arthur Silver Morton, University of Saskatchewan.

Peter Mitchell, Newcastle, New Brunswick.

\section{NATIONAL HISTORIC PARKS}

FORT ANNE NATIONAL HISTORICAL PARK situated in Annapolis Royal, Nova Scotia, covers 31 acres. 'The museum building, restored in 1935, was originally the Officers' Quarters and was built in 1797-98 under the supervision of Edward, Duke of Kent, the father of Queen Victoria, when he was Commander-in-Chief of the British forces in Nova Scotia.

Registration of visitors was 30,443 , an increase of 6,391 over last year.

PORT ROYAL HABITATION situated at Port Royal, near Annapolis Royal, Nova Scotia, covers 20.5 acres. A replica of the original Port Royal Habitation marks the exact site where the first European settlement 
in Canada, other than a mere trading post, was established in 1605 by the Sieur de Monts and Samuel de Champlain. Champlain himself chose the location and drew the picture of the building which was the chief source of information for the present replica.

Registration of visitors was 28,085 , an increase of 4,644 over last year.

FORTRESS OF LOUISBOURG NATIONAL HISTORIC PARK situated about three miles from the town of Louisbourg, Cape Breton Island, Nova Scotia, covers 339.5 acres. Louisbourg was a focal point in the struggle between English and French in North America which culminated in the possession of Canada for the British Crown. Built by the French after the Treaty of Utrecht in 1713 and named in honour of their sovereign, Louis XIV, the fortress was twice captured by the British and destroyed after the final conquest in 1758. Archaeological research is presently being conducted at Louisbourg by Mr. Russell Harper.

Total number of visitors who signed the register was 25,796 , an increase of 5,091 .

HALIFAX CITADEL NATIONAL HISTORICAL PARK (Halifax, Nova Scotia) situated on Citadel Hill, covers 37 acres and has a commanding view of the harbour and city. Four successive forts were built on its summit. The first was the strong point in a system of wooden blockhouses and palisades around the young settlement, designed to protect the settlers from Indians. The second was built during the American Revolution as a stronghold against the rebels. The third was constructed when Napoleon Bonaparte was endeavouring to conquer the world, and the existing one was started in 1828. The Citadel has been declared a National Historic Park and for some years the fortress, which had fallen into disrepair, has been under restoration.

Visitors who signed the register numbered 237,259, an increase of 3,259 from the previous year.

FORT BEAUSEJOUR NATIONAL HISTORIC PARK, situated near Sackville, New Brunswick, covers 81 acres. Built by the French, the fort was intended to be a stronghold against the undefined claims of the English to Acadia. Around the fort the Acadians had their homes and farms. It was captured by the British under Monckton in 1755 and renamed Fort Cumberland, after which time it was strengthened and its defenses extended by a system of advance entrenchments, traces of which still remain.

Visitor registration at the museum was 16,051 an increase of 2,273 over last year. 
FORT CHAMBLY NATIONAL HISTORIC PARK situated about twenty miles southeast of Montreal, on a conspicuous headland on the Richelieu River at Chambly, Quebec, covers 2.5 acres. The first fort, built by the French in 1665 as a protection against the Iroquois, was of wooden construction. It was later rebuilt of stone, this work being completed in 1771. In 1760 the fort was surrendered to the British, who, with a small garrison, occupied it until 1775 . In that year the Americans captured the fort, but evacuated it the following year. The fort was soon afterwards repaired and garrisoned by Sir Guy Carleton and later played an important part in the war of 1812 .

Visitors who signed the register in the museum numbered 56,804, a decrease of 16,161 from last year.

FORT LENNOX NATIONAL HISTORIC PARK, located on Ileaux-Noix in the Richelieu River, can be reached only by boat. This park, covering 210 acres, is about thirteen miles south of St. John's, Quebec. The present fort, which stands near the site of one previously erected by the French and a second fort constructed during the Revolutionary War, was built by the Imperial authorities in the period from 1819 to 1827. The island was acquired for historic site purposes in 1921, and extensive work has since been carried out on the buildings and grounds.

Attendance registration showed 10,816 persons, a decrease of 2,519 from the previous year.

FORT WELLINGTON NATIONAL HISTORIC PARK covers 8.5 acres and is situated at the east end of the town of Prescott, Ontario, adjacent to Highway No. 2. The fort, named after the Duke of Wellington, was first erected when the British authorities decided to fortify Prescott as one of the most vulnerable points of attack in the War of 1812, and as the main base for the defence of communications between Kingston and Montreal. It remains as it was when finally completed in 1838, an impressive landmark.

18,839 visitors registered, an increase of 1,433 over last year.

WOODSIDE NATIONAL HISTORIC PARK at Kitchener, Ontario, covers 11 acres. Its center of interest is a characteristic house of the 1850's where the Rt. Hon. William Lyon Mackenzie King spent his boyhood years in the 1880's.

Attendance was 2,046, an increase of 762 over last year.

FORT MALDEN NATIONAL HISTORIC PARK in Amhersburg, Ontario, covers 5 acres. The original fort was built in $1797-99$ by the Second Battalion, Royal Canadian Volunteers. It was strengthened in 1812 as the principal military station on the western frontier, and was 
dismantled and abandoned in 1813. Only slight evidences of the original fortifications remain, but the existing earthworks and the only old building still standing date from as early as 1823 .

28,855 visitors signed the museum register, which records an increase of 7,658 over last year.

LOWER FORT GARRY NATIONAL HISTORIC PARK situated on the west bank of the Red River about twenty miles north of Winnipeg, Manitoba, comprises an area of approximately 13 acres. It was built between 1831 and 1839 by the Hudson's Bay Company and, although never besieged, played an important part in meeting the threat of war and rebellion. Indian Treaty No. 1 was signed there on August 3,1871 . It remained a place of considerable importance until about 1882, when the head of navigation for the Red River was removed from there to old Colville Landing on the opposite side of the river near Selkirk. It was transferred to the Canadian Government in 1951, subject to the continuance of a lease of the buildings and grounds to the Motor Country Club for a further period.

The park is open to the public May Ist to October 31st. Hours are Monday to Friday 10:00 A.M. to 6:00 P.M. and Saturdays, Sundays and statutory holidays 10:00 A.M. to 5:00 P.M.

15,000 people visited the fort during the year, a decrease of 6,300 from last year.

FORT BATTLEFORD NATIONAL HISTORIC PARK situated in the Townsite of Battleford, four miles south of the City of North Battleford, Saskatchewan, comprises an area of 37 acres. The buildings include the Superintendent's House, Inspector's Cottage, Guard Room, Hospital, Stable and Barracks. Only the first-mentioned building was part of the original Mounted Police Post which was established there in 1876 by Colonel James Walker, and linked up with such posts as MacLeod, Fort Walsh, Calgary, Edmonton, Carleton, and Swan River. Located in the territory of the Cree Indian, Fort Battleford had a stabilizing and encouraging effect in the settlement of the Prairie Provinces, and, during the uprising of 1885, many settlers sought shelter and protection there. It was also the place of execution of those who were sentenced to death for participation in the Frog Lake Massacre.

Visitor attendance at the park rose from 15,214 in the preceding year to 18,099 .

SIGNAL HILL NATIONAL HISTORIC PARK covering 243.37 acres, overlooks the entrance to the harbour of St. John's, Newfoundland. On the hill is a memorial tower commemorating Cabot's explorations in North America. There is also a tablet erected on the site, commemorating 
the first wireless signal between the North American continent and Europe, which was transmitted by Marconi from a location near the tower. Also within the area in the vicinity of Signal Hill is located the position of the Chain Rock Battery, commanding the narrowest part of the harbour entrance and constructed after the French defeat in 1762; the Waldegrave Battery commanding the Narrows was built in 1810 and constructed on a knoll on the north of Chain Rock. There is also the blockhouse situated on the northern entrance of Signal Hill with six guns mounted on the ground floor, dated 1776; the Duke of York Battery, situated on the southern shoulder of the crest of Signal Hill, which in 1796 mounted eight 24-pounder guns, four 18-pounder carronades, and two 11-inch mortars. A chain of a very large size was fastened to a Chain Rock and lay across the Narrows with its other end fastened to a large capstan on Pancake Rock on the south side of the entrance, by which means it was raised sufficiently to prevent the entrance of any vessels larger than fishing boats.

The Signal Hill area was also the scene of a battle between the British under Colonel William Amherst and the French under Count d'Haussonville in the year when St. John's was finally captured, 1762, since when it has been held under the British Crown.

The powder magazine has been restored and repairs were made to the exterior of the Cabot Tower. A general clean-up of the park area has also been carried out, and an entrance road constructed.

The attendance was approximately 26,307 during the year, an increase of 25,805 over last year.

GRAND PRE NATIONAL HISTORIC PARK, at Grand Pré, Nova Scotia, covers 14 acres and includes the property on which stands the Gran Pré Chapel, built by the descendants of the Acadians over a period of eight years and opened as an historic museum in 1930. In its formal lines, planned to reflect mid-eighteenth century French architecture, the chapel preserves the memory of the original church of St. Charles. The museum collection includes maps, portraits, and documentary evidence relating to the Acadians, as well as relics of the first New England settlers in the Minas country.

Ornamental landscaping in the park complements the graceful beauty of Evangeline's Monument, the Memorial Chapel and the interest of "Evangeline's Well" with its wooden well sweep.

Visitors numbered 38,945 during the year, an increase of 7,583 from the previous year.

FOR'T LANGLEY NATIONAL HISTORIC PARK which is the Fort Langley site of the old Hudson's Bay Company post in B.C., has been taken over by the Federal Government. It occupies an area of 9 acres. 
The original fort built in 1827 was completely destroyed by fire in April, 1840. The trading post was rebuilt on a new site, the present village of Fort Langley, some two and one-half miles farther up the Fraser River.

By 1864 the fort was being gradually dismantled. The front and part of the stockade were taken down by degrees between 1861 and 1864, and the remainder was allowed to fall into disrepair. The growth of general farming in the colony caused the Hudson's Bay Company to abandon its fur trading in the Fraser Valley in June of 1896.

An old storehouse, which dates from 1840, is the only original building of the post now standing. Restoration of that building and of others in the fort is underway and construction of the palisades is continuing.

Visitors numbered 55,010 during the year, an increase of 52,510 .

FORT PRINCE OF WALES NATIONAL HISTORIC PARK covering an area of 50 acres, opposite the port of Churchill, Manitoba, is the most northerly fortress on the North American continent, and was built in the years between 1733 and 1771 by the Hudson's Bay Company to secure control of Hudson's Bay. In 1782, a French expedition, under La Pérouse captured the fort which was then stripped of all valuable items and demolished to a large extent. The fort, partially restored, stands today in much the same condition as La Pérouse left it.

Attendance registration numbered 425, a decrease of 75 persons from last year.

ALEXANDER GRAHAM BELL MUSEUM, at Baddeck, Nova Scotia was constructed in 1954-55 by the Department of Northern Affairs and National Resources, to present the scientific research of Dr. Bell through the displays contained therein. This park covers an area of 14 acres.

45,804 visitors registered last year, an increase of 9,751 over the previous year.

QUEBEC WALLS AND FORTIFICATIONS, Quebec.

Repointing and rebuilding the wall was continued.

SIR WILFRID LAURIER'S BIRTHPLACE at St. Lin-des-Laurentides, Quebec, covers an area of 1.5 acres.

Six thousand three hundred and sixty-three $(6,363)$ persons visited the site last year.

BATOCHE RECTORY, Batoche, Saskatchewan is a permanent monument to the battle in 1885 between the Métis, under Louis Riel and 
Gabriel Dumont, and the forces of General Middleton. On May 12th the Métis, after a brave offensive, were routed and Riel's movement was broken. Riel was captured three days later. The first floor will be used as a museum commemorating the events of 1885, as well as the life and customs of the Métis, the Indians, and the settlers of the district. The second floor will be restored as a school room and a post office, having been used for this purpose during the 1880's.

This site covers 1.5 acres.

Six hundred (600) persons registered as visitors, a decrease from last year of 200 . 